\title{
Deposition of Nickel and Cobalt by Chemical Reduction
}

\section{By Abner Brenner and Grace Riddell}

\begin{abstract}
A process has been developed for depositing nickel and cobalt from hot solutions of hypophosphite without the use of current. The reduction of metal occurs only on certain catalytic metal surfaces. By specific pretreatments, the adhesion of the deposits can be improved and by other pretreatments, the reduction can be induced on noncatalytic surfaces. The reduction can be inhibited completely by the presence of certain ions in the plating solution or by the catalytic metal surface becoming inactive. The possible mechanism of the reaction and the factors affecting the rate of deposition are discussed. The deposits produced by this process are sound, hard, and of good quality.
\end{abstract}

\section{Introduction}

Since the publication of a report by the authors ${ }^{1}$ of a process for depositing nickel by chemical reduction, additional information has been obtained that broadens the operating conditions and the applications of this process. The first paper described the deposition of nickel from an ammoniacal solution containing hypophosphite. The process has been extended to include the deposition of nickel from acid solutions and of cobalt and cobaltnickel alloys from ammoniacal solutions.

The process involves the reducing action of hypophosphites in a solution of nickel or cobalt at $90^{\circ} \mathrm{C}$ or above in the presence of certain catalytic metals. The reactions can be expressed by the following equations:

$$
\begin{array}{r}
\mathrm{NiCl}_{2}+\mathrm{NaH}_{2} \mathrm{PO}_{2}+\mathrm{H}_{2} \mathrm{O} \rightarrow \\
\mathrm{Ni}+2 \mathrm{HCl}+\mathrm{NaH}_{2} \mathrm{PO}_{3} \\
\text { or } \quad \mathrm{NaH}_{2} \mathrm{PO}_{2}+\mathrm{H}_{2} \mathrm{O} \rightarrow \mathrm{NaH}_{2} \mathrm{PO}_{3}+\mathrm{H}_{2} .
\end{array}
$$

The hypophosphite undergoes oxidation, and the nickel is reduced. Both of these components must be added at intervals to make the deposition continuous.

An interesting feature of the process is that the deposition of nickel or cobalt occurs only on certain metallic surfaces that are immersed in the hot

\footnotetext{
1 Abner Brenner and Grace E. Riddell, J. Research NBS 37, 31 (1946) RP1725: AES Annual Proceedings, p. 23 (1946).
}

solution, and that deposits are not usually obtained on the glass vessels. No electric current is involved in the deposition. It is suggested that this process be designated as "electroless nickel plating" and "electroless cobalt plating".

\section{Composition and Operating Charac- teristics of Solutions}

\section{Nickel}

(a) Alkaline Solutions

This subject, treated in the previous paper, will be reviewed briefly for completeness. The most satisfactory alkaline solutions are ammoniacal, and contain citrates, ammonium salts, hypophosphites, and nickel salts. A typical bath is composed of:

$\begin{array}{lr}\text { Nickel chloride_ } & \text { g/ter } \\ \text { Sodium hypophosphite } & 30 \\ \text { Ammonium chloride } & \\ \text { Sodium citrate } & \\ \text { Ammonium hydroxide to a pH of } 8 \text { to } 10 & \end{array}$

Such a solution deposits nickel at the rate of 0.0002 to 0.0003 in. (0.005 to $0.008 \mathrm{~mm}$ ) per hour.

As previously indicated, the rate of deposition depends upon the composition of the solution and is approximately proportional to the concentration of the hypophosphite, as shown in table 1. Varying the concentration of nickel salts within the limits shown produces no appreciable change in 
the rate of deposition. Other factors, such as the concentration of organic salt, effect the rate of deposition to a smaller degree.

TABLE 1. Effect of bath composition on rate of deposition

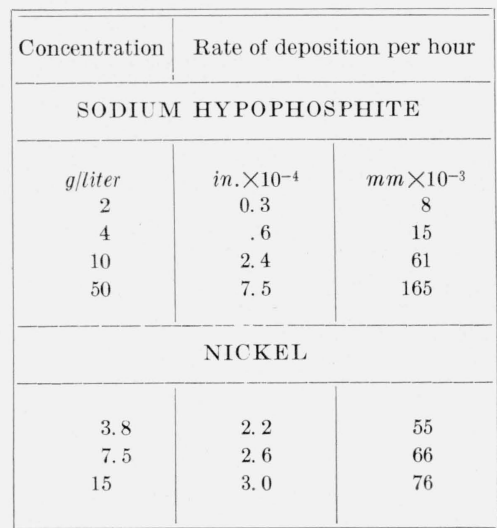

Table 2 indicates that the rate of deposition increases rapidly with temperature. This effect of temperature applies also to the acid-nickel solution and the alkaline cobalt solution, which will be discussed later.

TABLE 2. Effect of temperature on rate of deposition

\begin{tabular}{|c|c|c|}
\hline \multirow{2}{*}{ Temperature } & \multicolumn{2}{|c|}{ Thickness per 30 minutes } \\
\cline { 2 - 3 }${ }^{\circ}$ C. & in. $\times 10^{-4}$ & $m m \times 10^{-3}$ \\
54 & 0.155 & 0.39 \\
68 & .38 & .96 \\
78 & .64 & 1.63 \\
87 & .94 & 2.4 \\
92 & 1.1 & 2.8 \\
& & \\
\hline
\end{tabular}

If additions of hypophosphite are made at suitable intervals, the useful life of such a solution is relatively long. In a 1-liter bath, the equivalent of an area of 40 square decimeters was plated for 1 hour before the bath became inefficient. (This is equivalent to about 16 square feet for 1 hour in a 1-gallon bath). If the nickel concentration had been constant, and the solution had been filtered at intervals, the useful life of the solution would have been still greater.

\section{(b) Acid Solutions}

The alkaline-nickel solutions yield good, sound deposits, but in practice, their use is inconvenient and uneconomical, because at the high temperature of operation, there is a rapid loss of ammonia, and the fumes are disagreeable.
Earlier attempts to prepare an acid-nickel solution for electroless plating were unsuccessful. More recently an acid-nickel solution was formulated that overcomes the disadvantages of the alkaline solution. When the acid solution is used at elevated temperatures, no fumes or loss of constituents by vaporization occurs. The solution is more easily controlled and the deposits are produced at a faster rate than from alkaline solutions.

The proposed acid-nickel solutions differ from the alkaline-nickel solution in composition as well as in $\mathrm{pH}$. Typical bath compositions are given in table 3 .

TABLE 3. Composition of the acid-nickel solutions

\begin{tabular}{|c|c|c|c|c|}
\hline & \multicolumn{4}{|c|}{ Bath } \\
\hline & I & II & III & IV \\
\hline & g/liter & g/liter & g/liter & g/liter \\
\hline Nickel chloride, $\mathrm{NiCl}_{2} .6 \mathrm{H}_{2} \mathrm{O} \ldots \ldots$ & 30 & 30 & 30 & (n...... \\
\hline Nickel sulfate, $\mathrm{NiSO}_{4} .7 \mathrm{H}_{2} \mathrm{O}$ & - n. & - . & -...... & 30 \\
\hline Sodium hypophosphite, $\mathrm{NaH}_{2} \mathrm{PO}_{2} . \mathrm{H}_{2} \mathrm{O}$. & 10 & 10 & 10 & 10 \\
\hline Sodium hydroxyacetate, $\mathrm{NaC}_{2} \mathrm{H}_{3} \mathrm{O}_{3} \ldots \ldots$ & 50 & 10 & & $\ldots$ \\
\hline Sodium acetate, $\mathrm{NaC}_{2} \mathrm{H}_{3} \mathrm{O}_{2} .3 \mathrm{H}_{2} \mathrm{O}$ & & & & 10 \\
\hline Sodium eitrate, $\mathrm{Na}^{3} \mathrm{C}_{6} \mathrm{H}_{5} \mathrm{O}_{7} .51 / 2 \mathrm{H}_{2} \mathrm{O} \ldots$ & & & 10 & ... \\
\hline Rate of deposition: & & & & \\
\hline Millimeters per hour & 0.015 & 0.013 & 0.005 & 0.025 \\
\hline Inches per hour & .0006 & .0005 & .0002 & .001 \\
\hline Appearance of deposit & $\begin{array}{l}\text { Semi- } \\
\text { bright }\end{array}$ & $\begin{array}{l}\text { Semi- } \\
\text { bright }\end{array}$ & $\begin{array}{l}\text { Semi- } \\
\text { bright }\end{array}$ & $\begin{array}{c}\text { Rough, } \\
\text { dull }\end{array}$ \\
\hline pH.... & 4 to 6 & 4 to 6 & 4 to 6 & 4 to 6 \\
\hline
\end{tabular}

At a $\mathrm{pH}$ of 5 , nickel deposition will occur in a solution containing only soluble nickel salts and sodium hypophosphite. The reaction is vigorous, and the reduction of nickel is very rapid. Without any regulation of the $\mathrm{pH}$, the latter drops rapidly, and at a $\mathrm{pH}$ of 1 to 2 , the rate of deposition is low. In order to prevent the rapid drop in $\mathrm{pH}$, salts of organic acids are added as buffers, the most satisfactory being sodium acetate and salts of certain hydroxycarboxylic acids. These buffers maintain a high rate of nickel deposition, and the hydroxycarboxylic salts prevent precipitation of basic nickel salts.

To obtain the best deposits from a solution buffered by sodium acetate, its concentration must be carefully regulated. The data in table 4 indicate that large variations in the rate of nickel deposition results from changes in the acetate concentration. The rate of deposition reaches a maximum in the nickel-chloride bath with an acetate content of $2.5 \mathrm{~g} /$ liter; and in the nickel- 
sulfate bath, of $4.3 \mathrm{~g} /$ liter. The acetate can be added as barium, sodium, nickel, or other soluble salt. The acetate bath has the disadvantage of becoming turbid with use and of producing deposits that are dull and rough.

TABLE 4. Effect of acetate concentration on rate of deposition

\begin{tabular}{|c|c|c|c|}
\hline Bath composition & $\begin{array}{l}\text { Acetate } \\
\text { radical }\end{array}$ & $\begin{array}{r}\text { Thicknes } \\
\text { in }\end{array}$ & $\begin{array}{l}\text { f deposit } \\
\mathrm{hr}\end{array}$ \\
\hline \multirow{3}{*}{$\begin{array}{l}\text { Nickel sulfate, } 35 \mathrm{~g} / \text { liter, and sodium } \\
\text { hyrophosphite, } 10 \mathrm{~g} / \text { liter. }\end{array}$} & g/liter & in. $\times 10^{-4}$ & $\mathrm{~mm}$ \\
\hline & 2.0 & 7.5 & 0.02 \\
\hline & 6.5 & 4.0 & 02 \\
\hline \multirow{4}{*}{$\begin{array}{l}\text { Nickel chloride, } 30 \mathrm{~g} / \text { liter, ands odium } \\
\text { hypophosphite, } 10 \mathrm{~g} / \text { liter. }\end{array}$} & 1.0 & 2. 0 & .005 \\
\hline & 2. 5 & 6.0 & .015 \\
\hline & 6.5 & 1.0 & .0026 \\
\hline & 20.0 & 0. 6 & . 0016 \\
\hline
\end{tabular}

Certain hydroxycarboxylic acids, such as hydroxyacetic and citric acids, yield good rates of nickel deposition and likewise prevent precipitation of basic nickel salts, which cause rough deposits. Citrates produce deposits of good physical properties, but the rate of deposition is lower than from hydroxyacetate or acetate solutions. Tartaric, malic, gluconic, and formic acids are unsatisfactory because negligible amounts of nickel are deposited in their presence. Table 5 indicates that $50 \mathrm{~g}$ /liter and $100 \mathrm{~g}$ /liter of sodium hydroxyacetate give the highest rates of deposition, respectively, for the nickel-sulfate and nickel

TABLE 5. Effect of the concentration of hydroxyacetate on rate of deposition

\begin{tabular}{|c|c|c|c|}
\hline Bath composition & $\begin{array}{c}\mathrm{Na} \\
\text { hydroxy- } \\
\text { acetate }\end{array}$ & $\begin{array}{r}\text { Thicknes } \\
\text { in }\end{array}$ & $\begin{array}{l}\text { f deposit } \\
\mathrm{hr}\end{array}$ \\
\hline \multirow{4}{*}{$\begin{array}{l}\text { Nickel sulfate, } 35 \mathrm{~g} / \text { liter, and sodium } \\
\text { hypophosphite, } 10 \mathrm{~g} / \text { liter. }\end{array}$} & g/liter & in. $\times 10^{-4}$ & $m m$ \\
\hline & 50 & 4. 0 & .01 \\
\hline & 100 & 3.3 & .003 \\
\hline & 200 & 2.8 & .007 \\
\hline \multirow{3}{*}{$\begin{array}{l}\text { Nickel chloride, } 30 \mathrm{~g} / \text { liter, sodium } \\
\text { hypophosphite, } 10 \mathrm{~g} / \text { liter. }\end{array}$} & 10 & 4. 0 & .01 \\
\hline & 50 & 6. 0 & .015 \\
\hline & 100 & 7. 0 & .018 \\
\hline
\end{tabular}

chloride solutions. The concentrations of the other components may vary considerably. The nickel content may vary from 3 to $50 \mathrm{~g} /$ /iter without appreciably altering the rate of deposition, but with a nickel content of $100 \mathrm{~g} /$ liter, the rate of deposition is somewhat decreased.

Sodium hypophosphite can be used in concen- trations from 10 to $100 \mathrm{~g} /$ liter without appreciably affecting the rate of the process. This is in contrast to the behavior of the alkaline solution, in which the rate of deposition is nearly proportional to the concentration of hypophosphite.

The preferred $\mathrm{pH}$ range is from 4 to 6.5. As made up, the solutions have a $\mathrm{pH}$ of about 6 and no $\mathrm{pH}$ adjustment is required for a new bath. However, with long use, the $\mathrm{pH}$ drops slowly and, for continued rapid deposition, additions of a dilute hydroxide solution should be made at regular intervals. Because of the action of the buffer, frequent additions of hydroxide are not necessary. The alkaline solution used for the $\mathrm{pH}$ regulation should be dilute, so that the additions will not cause local precipitation of nickel compounds. Sodium and potassium hydroxide are used in preference to ammonium hydroxide, because large concentration of ammonium salts tend to lower the rate of the reaction.

The yield or efficiency of the reaction, calculated on the hypophosphite was determined by weighing the amount of nickel deposited on (1) a relatively large metal surface in a small volume of solution (i. e., 0.5. $\mathrm{dm}^{2} / 100 \mathrm{ml}$ ) and (2) a relatively small metal surface in a large volume of solution. (i. e., $0.5 \mathrm{dm}^{2} /$ liter) Under the first conditions, the average efficiency is 37 percent, i. e. about $2 \mathrm{~g}$ of nickel is reduced by $10 \mathrm{~g}$ of sodium hypophosphite. In the second procedure, the efficiency is only about 20 percent. Although both alkaline and acid solutions have about the same weight efficiencies, the rate of nickel deposition is larger in the acid solution.

\section{Cobalt}

(a) Alkaline Solutions

Some investigators ${ }^{2}$, by using highly concentrated solutions of hypophosphite, obtained cobalt in flake and powdered form by a reduction similar to that described for nickel. In the studies by Scholder and Heckel ${ }^{3}$, cobalt powder was obtained from a strongly alkaline tartrate solution. The black powder contained 90 to 92 percent of cobalt and 4 to 6 percent of phosphorus. The solution slowly decomposed upon standing at room temperature and the reaction became vigorous upon heating.

2 Paal and Friedrici, Ger. deut. chem. Ges. 64, 2561 (1931).

${ }^{3}$ Sholder and Heckel, Z. anorg. allgem. Chem. 198, 329 (1931). ' 
In the present studies, it was found that by reducing the concentration of the solution considerably, the formation of the powder was prevented, and smooth, adherent deposits of cobalt were formed on metal surfaces immersed in the hot solution. The alkaline-cobalt solution is very similar to the alkaline-nickel solution in composition and operation. It is composed of soluble salts of cobalt, hydroxycarboxylates, ammonia, and hypophosphite. The hydroxycarboxylic salts are used to prevent the precipitation of cobalt in the alkaline solution, and to afford deposits of good physical properties. The most suitable hydroxycarboxylic salts are the tartrate and citrate. Other salts, such as sodium hydroxyacetate, gluconate, and salicylate are unsatisfactory because they slow down the production of deposits. Deposits produced in the citrate solutions have better physical properties than those from the tartrate solutions, which tend to be more dull, powdered, and porous.

In the cobalt solution, ammonium salts decrease the rate of deposition to a considerable extent, in contrast to their effect in the alkaline nickel solution. However, this decrease in rate is compensated for by the fact that the deposits are superior in physical properties to the dull, rough, and porous deposits formed at exceedingly high rates in the solutions free from ammonium salts. The optimum concentration of ammonium salts is between 25 and $50 \mathrm{~g}$ /liter; an excessive amount, for example $100 \mathrm{~g} /$ /iter, decreases the rate of deposition to a negligible value.

The cobalt concentration should be between 2 and $10 \mathrm{~g} /$ liter. A concentration much above this causes darkening of the deposits and finally reduces the rate of deposition.

The sodium hypophosphite is used in higher concentrations in the cobalt than in the nickel solutions. Very little cobalt reduction occurs with sodium hypophosphite equal to $10 \mathrm{~g} /$ liter, but the rate of deposition is steadily increased as the hypophosphite concentration is increased to $100 \mathrm{~g} /$ liter. For optimum efficiency, it is recommended that the sodium hypophosphite content be $20 \mathrm{~g}$ /liter.

For most purposes, ammonium hydroxide is used to regulate the $\mathrm{pH}$ of the solution. Other hydroxides can be used, but, when this is done, more care is required in making additions in order to keep within the $\mathrm{pH}$ range.
Table 6 shows the composition of some typical baths. Bath IV produces deposits of superior physical properties. However, deposition may be slow to start, and in such cases, it can be initiated in bath II before the parts to be plated are immersed in bath IV.

TABLE 6. Compositions of some of the alkaline-cobalt solutions

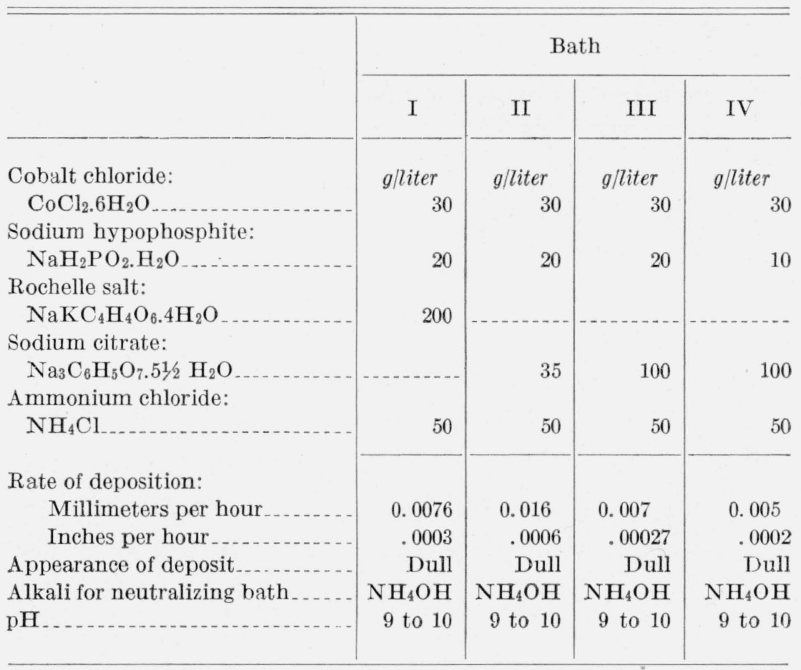

The $\mathrm{pH}$ of the solutions has a considerable effect upon the rate of deposition. For best results, the $\mathrm{pH}$ should be kept above 9 for the cobalt, whereas, a $\mathrm{pH}$ of 8 to 9 was satisfactory for the alkaline nickel solutions. The yield or efficiency of the deposition of cobalt, based on the decomposition of hypophosphite, is 66 percent when a relatively large surface is coated in a small volume of solution. When the area of metal surface in a given volume of solution is decreased, the efficiency is lowered.

\section{(b) Acid Solutions}

The reduction of cobalt from acid baths is not satisfactory. A very thin film of cobalt forms on copper and steel in solutions of certain compositions, but the deposit does not build up and covers irregularly. From experiments in which the composition, concentration, metal surfaces, and pretreatments were varied widely, it was concluded that deposition from acid solutions is impractical.

\section{Solutions for Depositing Nickel-Cobalt Alloys}

A deposit of a nickel-cobalt alloy can be obtained by using an alkaline solution containing soluble salts of both metals. In a solution con- 
taining equal parts of nickel and cobalt, the resulting deposit contains about 65 percent of nickel. When the metal ratio, $\mathrm{Co} / \mathrm{Ni}$, in the solution is changed to 2 , the resulting deposit contains about 50 percent of each metal.

The conditions for plating, with respect to $\mathrm{pH}$, temperature, and composition, are the same as for alkaline electroless plating of nickel or cobalt. The $\mathrm{pH}$ should be 8 or above, and the temperature at least $90^{\circ} \mathrm{C}$. A typical alloy bath contains:

$\begin{array}{lr}\text { Cobalt chloride_ } & \text { g/liter } \\ \text { Nickel chloride_. } & 30 \\ \text { Sodium citrate_. } & 50 \\ \text { Ammonium chloride } & \\ \text { Sodium hypophosphite } & \\ \text { Ammonium hydroxide to regulate pH. }\end{array}$

This solution deposits a semibright cobalt-nickel alloy at the rate of nearly $0.0006 \mathrm{in} .(0.015 \mathrm{~mm})$ in 1 hour. Changes in the composition of the solution cause changes in the rate of deposition and in the physical properties of the deposit that are similar to those mentioned for the individual metals. When sodium citrate $(100 \mathrm{~g}$ /liter $)$ is used in place of Rochelle salts, the deposits are brighter and smoother, but the corrosion resistance is inferior.

In the acid solution, an alloy cannot be obtained, as nickel alone is deposited. Only 0.25 percent of cobalt was found in a deposit from an acid solution containing equal amounts of each metal.

\section{Effects of Impurities}

Certain metals and radicals in the plating solutions decrease the rate of metal reduction. Table 7 shows the concentrations at which some metals will inhibit plating.

TABLE 7. Effect of impurities

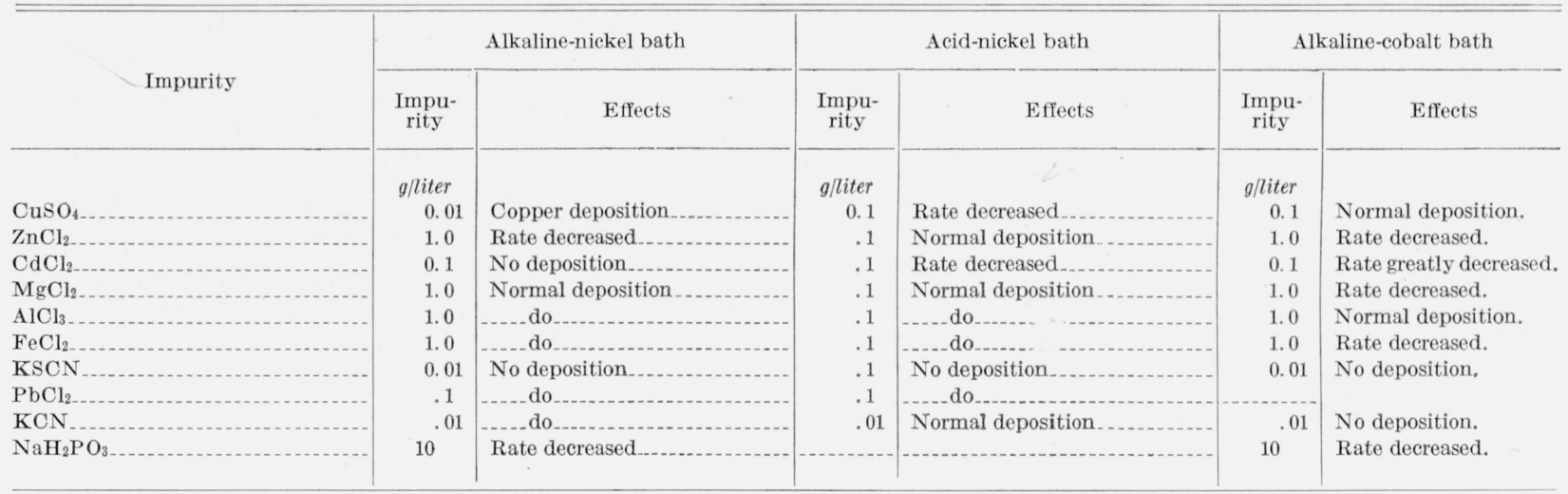

The cobalt solution is the most sensitive, and the acid-nickel solution the least sensitive to impurities. Palladium does not inhibit the deposition, but it causes a gradual decomposition of the hypophosphite when present in the solution.

To render the contaminated solutions operable again, the impurities must be removed. The removal can be made by conventional means of separation. For example, the suggested manner for removing cadmium from the solution is to adjust the bath to $\mathrm{pH} 3.5$ to 4.0 and to pass hydrogen sulfide through the solution for about 15 minutes. The cadmium is precipitated under these conditions and it can be separated by filtering. If the $\mathrm{pH}$ of the solution is above 4 , much nickel is precipitated, and if the $\mathrm{pH}$ is below 3, the cadmium precipitation is not complete.
Frequently, failure to plate is caused by poisoning of the metal surface. An interesting example of this is the passivation of a gold surface by cyanide solutions. Massive palladium does not always have the catalytic properties shown by the freshly prepared palladium film.

\section{Deposition on Various Surfaces}

Iron, nickel, gold, cobalt, aluminum, and palladium have catalytic properties that initiate the reduction of the nickel and cobalt immediately upon their introduction into the hot solution. Zinc surfaces reduce some nickel, but the deposits have very poor physical properties. Some metals, particularly silver, occasionally act as catalytic surfaces. 
Deposition can be obtained on noncatalytic metal surfaces such as platinum, copper, and brass, if certain measures are taken prior to immersing the metal into the plating solution. Lead and cadmium are noncatalytic metals that are not favorably affected by pretreatments, and deposition cannot be induced upon their surfaces. To induce deposition on specific noncatalytic surfaces and on certain catalytic surfaces that may be temporarily passivated, three methods may be used: (1) Change the composition of the plating solution (applicable to alkaline solutions only), (2) make contact with a more electronegative metal, and (3) deposit a thin layer of a catalytic metal on the surface of the noncatalytic metal. The latter two processes are applicable to both alkaline and acid solutions.

Procedure (1). Copper and brass can be plated in alkaline solutions containing no ammonium salts, but these solutions are not as stable as the ammoniacal solutions that have been recommended previously. As much as $0.0001 \mathrm{in}$. $(0.0025 \mathrm{~mm})$ of nickel is deposited on copper in 30 minutes from solutions containing:

$\begin{array}{lr}\text { Nickel chloride. } & \text { g/titer } \\ \text { Sodium hypophosphite } & 20 \\ \text { Rochelle salt_. } & 200 \\ \text { Sodium hydroxide to regulate } \mathrm{pH} \text { to } 8 \text { to } 10 .\end{array}$

Because of the instability of this solution, this procedure is not of practical value. If an excess of sodium or potassium hydroxide is used in regulating the $\mathrm{pH}$, metal compounds will precipitate, and in turn, may act as nuclei for vigorous reduction of the metal and thus cause rapid decomposition of the solution. It is of interest that, although metal reduction is induced on copper surfaces in this type of solution, it does not consistently occur on steel surfaces. This is opposite to the behavior of these metals in the ammoniacal solutions.

(2). It was learned in this research that some noncatalytic metals can be plated by momentarily bringing a more electronegative metal, such as aluminum or iron into contact with the surface of the article while it is immersed in the electroless solution. ${ }^{4}$ The contact needs to be of only short

\footnotetext{
4 William Paecht of the Wright Aeronautical Corp., in a subsequent communication to the authors, suggested the use of iron or steel for this purpose. A copy of a note was recently received that was published in Science and Culture (Calcutta), 12, 503 No. 10 (April 1947), by A. P. Goswami. He also reported successful deposition of nickel on copper, brass, and platinum by bringing them into contact with steel.
}

duration to initiate the deposition on the noncatalytic surface. Once the plating is started, presumably as a result of galvanic action, the reduction continues on the nickel that is first deposited. By this procedure, such metals as silver, copper, and brass can be activated so as to cause deposition of nickel upon their surfaces. Lead cannot be so plated. See table 8 .

TABLE 8. Pretreatments for noncatalytic surfaces + , surface will plate; - , surface will not plate

\begin{tabular}{|c|c|c|c|c|c|c|}
\hline \multirow{2}{*}{ Metal surface } & \multicolumn{3}{|c|}{ Contact process } & \multicolumn{3}{|c|}{ Palladium dip } \\
\hline & $\begin{array}{l}\text { Alka- } \\
\text { line Ni }\end{array}$ & $\begin{array}{l}\text { Acid } \\
\mathrm{Ni}\end{array}$ & $\begin{array}{c}\text { Alka- } \\
\text { line Co. }\end{array}$ & $\begin{array}{c}\text { Alka- } \\
\text { line Ni }\end{array}$ & $\underset{\mathrm{Ni}}{\text { Acid }}$ & $\begin{array}{l}\text { Alka- } \\
\text { line Co. }\end{array}$ \\
\hline Copper.... & + & + & + & + & + & + \\
\hline Brass ....... & + & + & + & + & + & + \\
\hline Platinum ... & + & + & + & - & - & - \\
\hline Gold a ....... & + & + & + & + & + & + \\
\hline Silver ...... & + & + & + & ... & - & - \\
\hline Lead . . . . & - & ......... & - & - & - & - \\
\hline
\end{tabular}

a Although gold is listed as catalytic for this process, it is frequently inactive.

(3). The third method of initiating deposition involves depositing minute amounts of catalytically active metals, such as palladium or rhodium, upon the noncatalytic surface. This can be done by dipping the metal into a solution containing palladium, $0.02 \mathrm{~g} /$ liter, and $\mathrm{HCl}$ (20 ml/liter). This dip is made after the conventional cleaning, and immediately prior to immersion in the hot nickel solution. The immersion deposit of palladium is visible as a faint tarnishing, and is sufficient to catalyze the nickel reduction. This procedure is particularly satisfactory for obtaining deposits of nickel on copper and copper base alloys. The time required for immersion is dependent upon the cleaning treatment that the metal is given prior to the palladium dip, and also upon the temperature of the palladium solution.

Though not always necessary, a preliminary bright dip (in $\mathrm{H}_{2} \mathrm{SO}_{4}$ and $\mathrm{HNO}_{3}$ or $\mathrm{H}_{3} \mathrm{PO}_{4}$ and $\mathrm{HNO}_{3}$ ) is recommended for copper and brass surfaces. If copper is given a bright dip, the time required for immersion in the palladium solution at $25^{\circ} \mathrm{C}$ is only a few seconds; otherwise the immersion in the palladium solution should be increased to several minutes. With or without a bright dip, brass should be immersed in a palladium solution at $60^{\circ} \mathrm{C}$ for about 1 minute.

In spite of palladium being a precious metal, 
this treatment is relatively inexpensive, because of the very small amount of palladium consumed by the process. At the current price of palladium (about $\$ 1$ per $\mathrm{g}$ ), the solution will not cost more than about $\$ 0.02$ per liter. Only very thin films of palladium are required; in fact the film used is almost of unimolecular thickness, (about $2 \times 10^{-8}$ cm or $8 \times 10^{-9}$ in.) as judged by the palladium consumption. One liter of solution, containing $0.01 \mathrm{~g}$ of palladium, is sufficient to treat nearly 200 $\mathrm{dm}^{2}\left(20 \mathrm{ft}^{2}\right)$ of metal surface.

Plastic surfaces are noncatalytic, and none of the above procedures will initiate the nickel deposition. In an endeavor to plate plastics, several types were tried in the hot nickel solution. Even when precleaned with organic solvents and acids, the plastics remained noncatalytic. No deposition occurred on the surface when immersed in highly concentrated solutions. When a plastic was silvered prior to immersing in the nickel solution, satisfactory deposition failed to occur. This failure was due primarily to the silver flaking from the plastic in the hot solution. Other methods of applying a metal film to the plastic might be more successful.

\section{Mechanism of the Reaction}

The data given in section II regarding the effect of concentration of the bath constituents on the rate of reaction show that the reaction does not go according to the equations. If the reaction proceeded in the fashion expressed in eq 1, the rate of deposition of nickel would be proportional to the concentration of hypophosphite and nickel. As previously discussed, the rate of deposition in the acid solution is virtually unaffected by the concentration of the reactants, and in the alkaline solution is affected only by the concentration of the hypophosphite and not by that of the nickel. Therefore, the reaction does not follow a simple course, but undergoes intermediate steps.

Actually, the rate of the reaction is affected as much by the change in $\mathrm{pH}$ and the concentration and specific nature of the organic salts as by the concentration of the primary reactants. We have attempted to explain the reaction by one of two hypothesis, neither of which is applicable to all the phenomena.

One suggested mechanism is that the reaction that determines the rate is the reaction of hypo- phosphite (eq 2) to produce hydrogen which, in turn, reduces the nickel on the catalytic surface. There is some evidence to support this mechanism for the alkaline solutions. Hydrogen evolution occurs at the surface of catalytic metals, even in the absence of nickel or cobalt salts, when immersed in the hot alkaline hypophosphite solutions. Furthermore, the potential of the catalytic metal in this solution is the same as the potential of the metal during the electroless plating process. The potential is -1.1 to $-1.2 \mathrm{v}$, relative to the saturated calomel electrode (see table 9 ). This potential is more negative than the reversible potential of either hydrogen or nickel, and hence is sufficient to account for the separation of the free elements.

TABLE 9. Electrode potentials (against saturated calomel electrode) in an ammoniacal nickel solution

\begin{tabular}{|c|c|c|}
\hline \multirow{2}{*}{ Electrode } & \multicolumn{2}{|c|}{$\begin{array}{l}\text { Potential with re- } \\
\text { spect to saturated } \\
\text { calomel electrode }\end{array}$} \\
\hline & $\begin{array}{l}\text { Before } \\
\text { plati g }\end{array}$ & $\begin{array}{l}\text { After } \\
\text { plating }\end{array}$ \\
\hline Steel ........ & & -1.16 \\
\hline Aluminum & ......... & -1.2 \\
\hline Platinum ........ & -0.44 & a -1.2 \\
\hline Copper & -.60 & a -1.25 \\
\hline Silver . . _ & -.17 & a -1.15 \\
\hline Gold $\ldots \ldots \ldots$ & -.04 & $\mathrm{~s}-1.23$ \\
\hline
\end{tabular}

a Plating induced by contact with aluminum.

This explanation does not apply to the reaction in the acid solution in which, as already emphasized, the rate of deposition is not affected by the concentration of the hypophosphite. Furthermore, the catalytic decomposition of hypophosphite with the production of hydrogen does not occur at metallic surfaces in the absence of nickel salts. The fact that the rate of deposition of nickel is increased considerably by the movement of the metal being plated would seem to indicate that the rate may be controlled by some type of diffusion process. Agitation of the metal does not affect the rate in the ammoniacal solution. Therefore, the mechanism seems to be different for acid and alkaline solutions.

Another possible mechanism for electroless plating is that the presence of hydrogen on the catalytic metal constitutes a galvanic cell, in which hydrogen is the anode and the metal the cathode. The process could then be considered as electrolytic. The potential of the metal during the 
electroless process is negative enough for such to be the case in both the acid and alkaline solutions. (See table 10.) An objection to this mechanism is that from an acidic electroless solution containing equal amounts of cobalt and nickel, only nickel is deposited. If this were an electrolytic process, more cobalt would be deposited than nickel.

TABLE 10. Summary of potentials (against saturated calomel electrode) in solutions containing hypophosphite

\begin{tabular}{|c|c|c|c|}
\hline \multicolumn{2}{|r|}{ Solutions } & \multirow{2}{*}{ Condition of electrode } & \multirow{2}{*}{$\begin{array}{l}\text { Aver- } \\
\text { age } \\
\text { poten- } \\
\text { tial }\end{array}$} \\
\hline No. & Composition & & \\
\hline A & $\begin{array}{l}\text { Alkaline nickel with ammo- } \\
\text { nium salts. }\end{array}$ & During deposition & -1.2 \\
\hline B & $\begin{array}{l}\text { Alkaline nickel with no am- } \\
\text { monium salts. }\end{array}$ & _..... do & -1.3 \\
\hline $\mathrm{C}$ & Same as B, but without nickel & As hydrogen evolntion occurs & -1.3 \\
\hline $\mathrm{D}$ & $\begin{array}{l}\text { Alkaline cobalt with ammo- } \\
\text { nium salts. }\end{array}$ & During deposition & -1.2 \\
\hline $\mathrm{E}$ & $\begin{array}{l}\text { Acid nickel with hypophos- } \\
\text { phite and organic salt. }\end{array}$ & $\ldots$ do & -0.9 \\
\hline $\mathrm{F}$ & Same as E, but without nickel. & $\begin{array}{l}\text { No observable reaction at } \\
\text { catalytic surfaces }\end{array}$ & -.8 \\
\hline $\mathrm{G}$ & $\begin{array}{l}\text { Same as E, but without hypo- } \\
\text { phosphite. }\end{array}$ & $\begin{array}{l}\text { During electrolysis at } 0.5 \\
\mathrm{amp} / \mathrm{dm}^{2} \text {. }\end{array}$ & -.77 \\
\hline $\mathrm{H}$ & _. do & Theoretical $\mathrm{H}_{2}$ potential & .59 \\
\hline
\end{tabular}

In connection with the measurement of the potentials of electroless plating, it was of interest to determine the effect of impurities on the potentials. As small concentrations of cadmium inhibit deposition, this impurity was selected for study. The addition of cadmium to the extent of 100 $\mathrm{mg} /$ liter in the course of an electroless plating experiment caused the potential of the work to become more noble, as shown in the following data, and both the metallic deposition and hydrogen evolution ceased. (Potentials measured against calomel half-cell.)

Potential of steel before hypophosphite is added to the bath _........... 1.15

Potential of surface while plating with hypophosphite added to the bath..... - 1.28

Potential of surface after cadmium chloride, $0.01 \mathrm{~g} /$ liter is added to bath ........ . -1.14

\section{Adhesion of Deposits}

The adhesion of the deposits to the base metal is such that the deposits will not flake off, but in some cases will detach on flexing. The adhesion to various metals can be improved by variations in the cleaning of the metal prior to immersion in the reducing solution. Excellent adhesion to steel can be obtained by an anodic treatment of the steel in a 70-percent sulfuric acid, but in order to make the process independent of current, it is preferable to use a dip in concentrated (95\%) sulfuric acid.

The adhesion to surfaces that have been given a palladium dip may be inferior because of the usually poor adhesion of immersion coatings of palladium to the base metal. The adhesion of the nickel to aluminum surfaces is unsatisfactory, but can be improved if the aluminum is given a zincate dip prior to immersion in the reducing solution.

\section{Physical Properties of the Deposits}

\section{Microstructure}

As shown by figures 1, 2, and 3, the deposits have laminations running parallel to the base metal, and within each layer there is a columnar structure perpendicular to the base metal. Figures 2 and 3 show that upon heating, precipitation occurs.

\section{Hardness}

The hardness of the electroless nickel deposits is greater than that of electrodeposited nickel. The Knoop hardness number for nickel, electrodeposited in a Watts type bath, may vary from 120 to 450 . For the electroless nickel from the alkaline citrate solution, the hardness is about 425 , and from the ammoniacal solution containing no organic salts, about 530. Deposits from the acid-nickel solution have an average hardness of about 500. Upon heating the electroless nickel deposits, their hardness is increased; this is in contrast to the so-called "hard" nickel that is usually electrodeposited from a bath containing ammonium salts and has an initial hardness of about 500, but which softens upon heating. A possible explanation of this difference may be the occurrence of precipitation hardening in the electroless deposits. As formed, the electroless deposits are brittle, but they become ductile upon heating. 


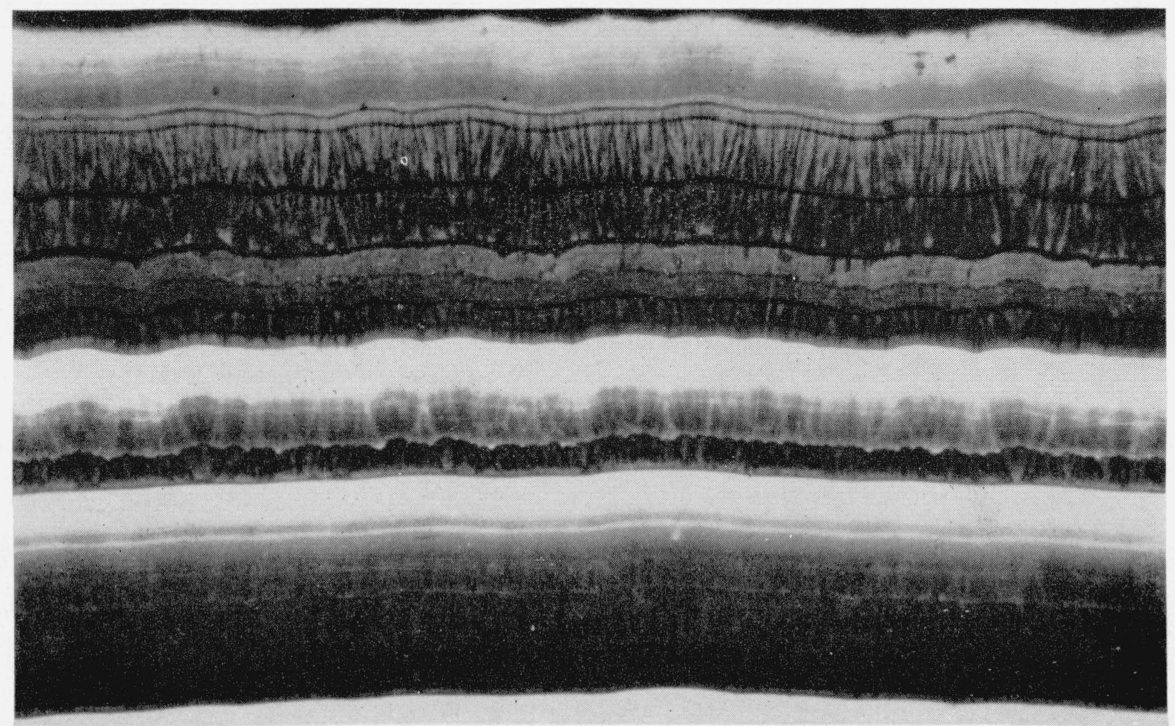

FIGURE 1. Electroless nickel deposit from an acid solution showing laminations and columnar structure, $\times 500$. Knoop hardness number 500 .

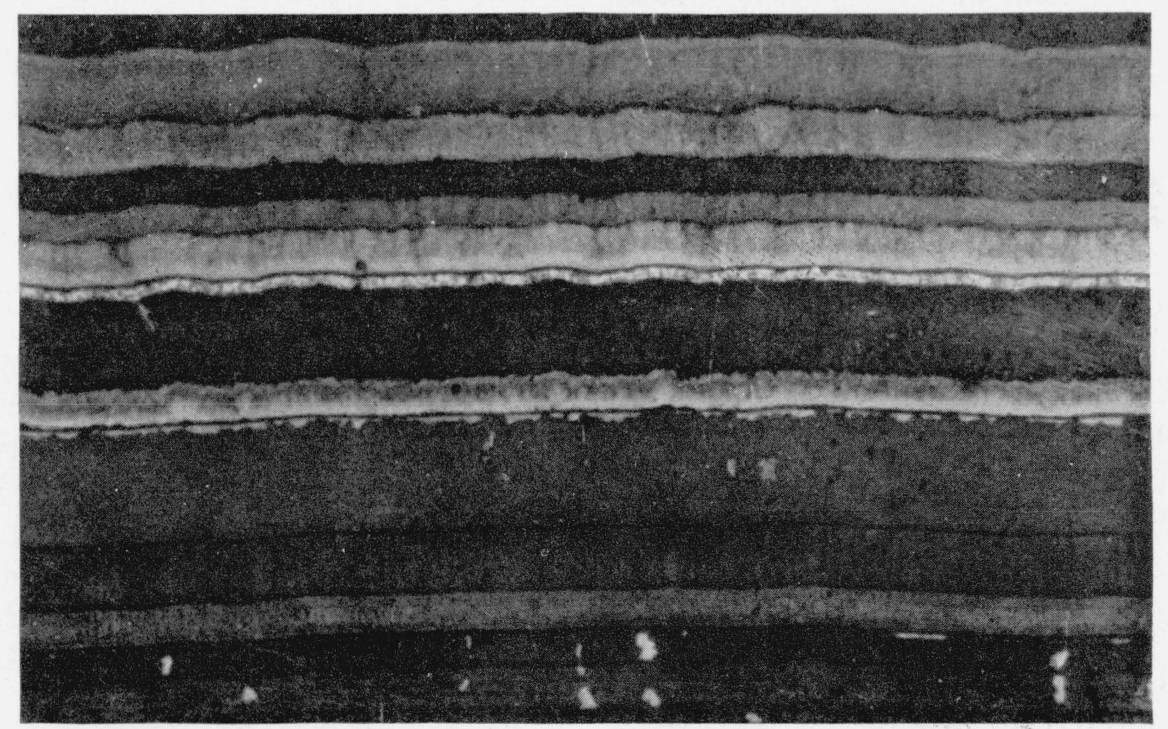

Figure 2. Electroless nickel deposit, after annealing at $400^{\circ} \mathrm{C}$ for $1 / 2 \mathrm{hr}, \times 500$. Knoop hardness number 800 . 


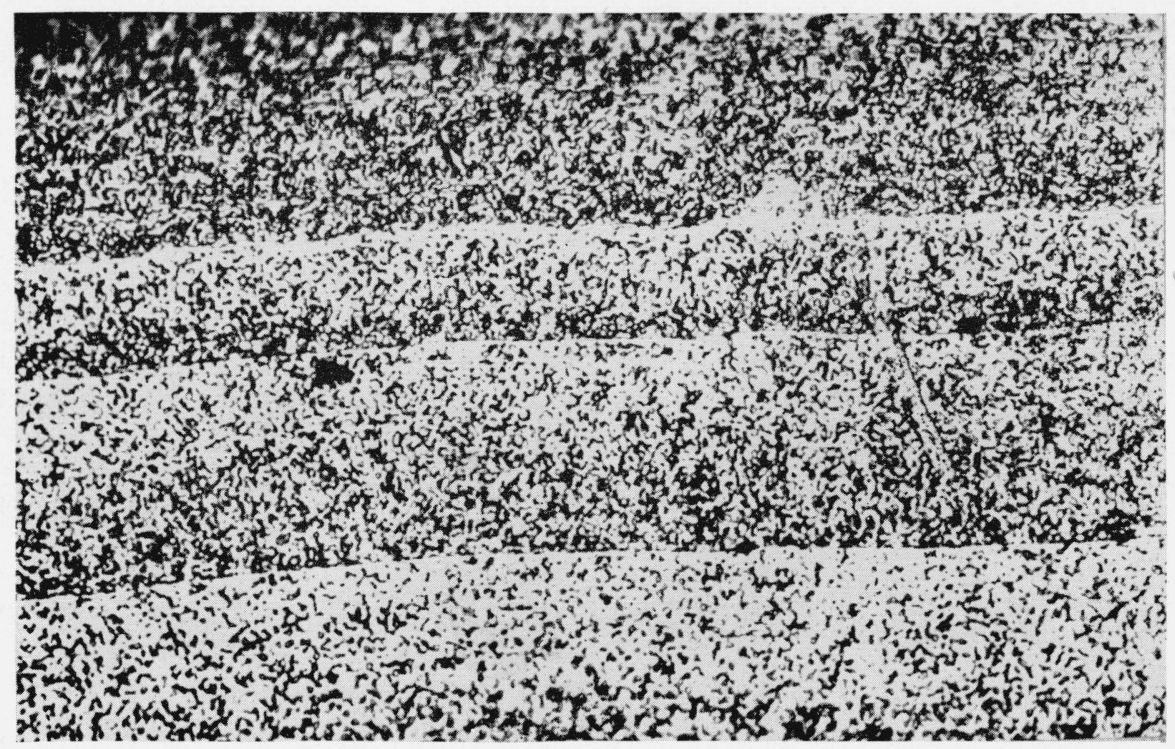

FIGURE 3. Electroless nickel deposit, after annealing at $800^{\circ} \mathrm{C}$ for $1 / 2 \mathrm{hr}$, showing apparent precipitation, $\times 500$. Knoop hardness number 470.

\section{Magnetic Properties}

Qualitative measurements of magnetic properties were made by measuring the attractive force of a permanent magnet for the coating. It was found that the electroless nickel is not as magnetic as electrodeposits from the Watts nickel bath. The magnetic properties of electroless nickel are increased by annealing at $400^{\circ} \mathrm{C}$ for about 30 minutes.

\section{Appearance}

In general, the alkaline nickel solutions produce the brightest deposits. Deposits from the acidnickel solutions can be brightened somewhat by the addition of cobalt or very small amounts of cadmium $(0.01 \mathrm{~g} /$ liter $)$, but by such additions, the rate of deposition is decreased. The cobalt deposits are dull (similar to electroplated cobalt in appearance) and tend to be dark when deposited at high rates.

\section{Corrosion Resistance}

In the 20-percent salt-spray test, electroless nickel, deposited on steel from either the acid or alkaline solutions, affords protection to the steel equal to that of electroplated nickel. The cobalt deposits from the citrate solutions give protection to steel superior to those from the tartrate solutions, but neither are comparable to electroplated deposits of the same thickness. The electroless deposits of $\mathrm{Co}-\mathrm{Ni}$ alloy fail in the salt spray sooner than the single deposits of cobalt or nickel.

\section{Composition}

Nickel deposits from the alkaline solutions contain an average of 93.5 percent of nickel and from the acid solutions, an average of 93.1 percent of nickel. The electroless cobalt deposits contain 94.5 percent of cobalt. Although quantitative analysis has not been made, qualitative tests indicate that the deposits contain considerable amounts of phosphides.

\section{Reaction with Ferric Chloride}

By immersing electroless nickel deposits in an acid solution of ferric chloride, $200 \mathrm{~g}$ /liter, the metallic surface is blackened. It has not been possible to produce a uniform degree of blackening, and hence this property has little commercial value. The electroless black nickel does not protect steel in the 20-percent salt spray tests as well as does electroplated black nickel of the same thickness.

\section{Possible Analytical Applications}

\section{Detection of Palladium}

As previously described, reduction in the hypophosphite solutions can be initiated by the presence of small amounts of palladium. Feigl 
and Frankel ${ }^{5}$ used this reaction to detect palladium. They added the unknown to a hot solution containing nickel and hyposphite and observed the formation of a powder or mirror of nickel on the wall of the test tube. They were able to detect one part of palladium in a billion parts of solution.

As a result of our work, an alternative procedure is suggested as being more direct. A cleaned copper wire is immersed in an acidified solution to be tested; any palladium present will tend to be reduced on the copper surface. Nickel will then reduce on the wire upon introducing the latter into the typical electroless hypophosphite solution (composition suggested in section II, 1 , (a). This is not a specific test, as rhodium will also cause copper to react in a similar manner.

${ }^{5}$ Ber. deut. chem. Ges. 65. [B], 539 (1932).

\section{Quantitative Reduction of Nickel}

Paal and Freiderici ${ }^{6}$ reduced nickel compounds to the metal in an ammoniacal hypophosphite and tartrate solution. They were not able to obtain complete precipitation of the metal by this method.

In the present studies, a quantitative reduction of nickel was obtained by increasing the concentration of the sodium hypophosphite to 50 $\mathrm{g} /$ liter and that of ammonium chloride to about $600 \mathrm{~g} /$ liter. The reaction occurred spontaneously without a catalyst being present. The nickel powder was separated by filtration, leaving the filtrate free from nickel as indicated by a test with dimethylglyoxime. The utility of this separation has not been investigated.

Washington, July 18, 1947.

${ }^{6}$ Ber. deut. chem. Ges. 64, 1766 to 1776 (1931). 